\section{Hamsun og Esmann hos Nimb 1903 \\ Omkring nogle skitser af Ludvig Find - et bidrag til Knut Hamsuns portrætgalleri}

\section{af mag.art. Bo Alkjicr, Det Kongelige Bibliotek.}

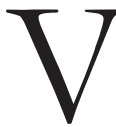
ed gennemgang af nogle kunstner- og forfatterbreve stødte jeg tilfældigvis på et par portrætskitser, som syntes at stamme fra den periode, hvor Knut Hamsun var i kontakt med det danske kunstnermiljø. I forbindelse med forsøget på en nærmere identifikation og datering af et formodet ukendt Hamsunportræt søgte jeg assistance og oplysninger fra Norsk Portrettarkiv og Frederiksborgmuseet. ${ }^{1}$ Jeg konstaterede imidlertid nogle huller i de registranter, man kan få adgang til der. I den følgende redegørelse for en helt specifik dateringsproces vil der derfor også blive lejlighed til at give supplerende oplysninger og drage et par andre tilsyneladende upåagtede portrætter fra perioden frem i lyset.

En ny portrætskitse føjer måske ikke så meget nyt til det i forvejen kendte billede, men konteksten kan blive værdifuld, da en brik med en nok så ubetydelig detalje jo ofte er den, der får flere brikker i det biografiske puslespil til at falde på plads.

I 2009 blev 150-året for Knut Hamsuns fødsel fejret med teaterforestillinger, udstillinger og nyudgivelser ledsaget af debat og heftig polemik for og imod dyrkelsen af nobelpristageren med det blakkede ry. Tilhængere og modstandere var dog enige om at Hamsun er værd at beskæftige sig med både på grund af hans artistiske formåen, og fordi hans forfatterskab, liv og skæbne har fået eksempelstatus i det brændpunkt, der samler det sene nittende århundredes æstetiske og filosofiske strømninger og deres tvetydige betydning for det tyvendes politiske eksperimenter.

Det begyndte på Nietzsches tid, som Sophus Claussen husker som: Aarene, da Knut Hamsun hjemvendt fra Amerika gik omkring som en ung Gud i Københavns Støv; ${ }^{2}$ her blev han feteret og poserede villigt i fotoatelieret efter gennembruddet med romanen Sult. Hamsuns portrætgalleri fra 1890erne og fremefter er mangfoldigt. Allerede i 1891 lod han sig male i stort format. ${ }^{3}$ Man kan følge forvandlingen af den unge charmeur til betydningsfuld forfatter gennem skiftende frisurer og skægmoder til viljemenneske i Nietzschestil og videre gennem den med berømmelsen stigende strøm af officielle portrætter og pressefotos helt frem til den nisseskæggede olding.

Kendte og ukendte fotografier gengives i mange af de rigt illustrerede bøger om den forkætrede forfatter, men noget samlet overblik over hele det fotografiske portrætgalleri er det ikke let at få. Det samme gælder avis- og vittighedstegninger. ${ }^{4}$

Anderledes med de samtidige kpnstnerportrætter. Her findes der billedregistranter og fortegnelser på lidt over 30 numre fra Hamsuns levetid. 10 fra tiden før $1914 .^{5}$ 


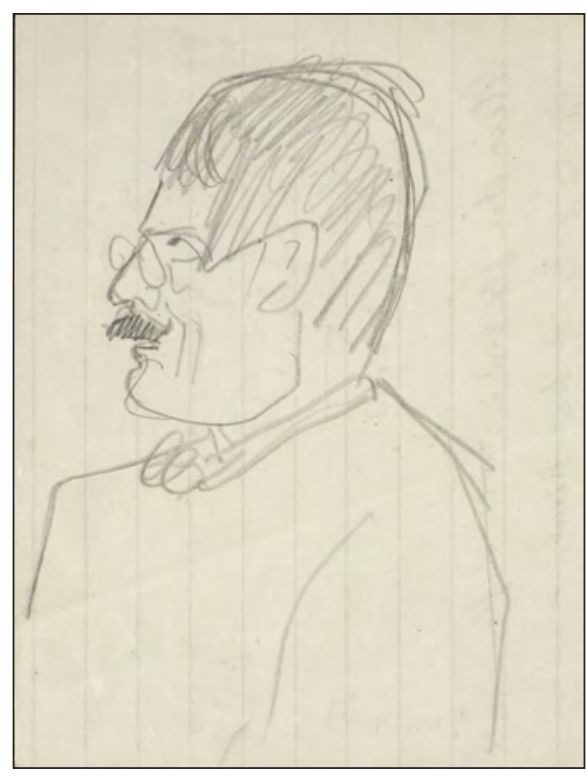

Knut Hamsun? Unavngiven profil på bagside af udateret brev. Blyantstegning $(82 \times 117 \mathrm{~mm})$ af Ludvig Find (Det Kongelige Bibliotek).

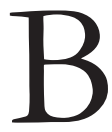
ag på et udateret brev har Ludvig Find $^{6}$ på det sammenfoldede brevpapir tegnet nogle blyantsportrætter i en hastig karikaturagtig streg. Det ene, et profilbillede, synes at skulle karakterisere en person ved viltert pandehår, strittende overskæg og kraftigt kæbeparti. Mandspersonen er ikke navngivet - kunstneren har måske ikke været helt tilfreds med udførelsen - men manden ligner Hamsun, som man kender fra portrætgalleriet, med moustache og lorgnetter. En vis lighed med Finds med navn betegnede tuschtegning på Frederiksborgmuseet understøtter identifikationen med den norske forfatter. Der er mere sikker penselføring i denne udaterede skitse, som tilsyneladende er forblevet upåagtet skønt gengivet i 1946 i en bog om Gustav Wied. ${ }^{7}$

På samme side af brevet, men omvendt, er der en anden tegning med kunstnerens egenhændige betegnelse: Esmann (se nedenfor) - efter alt at dømme et meget vellignende portræt af forfatteren Gustav Esmann. ${ }^{8}$

Hvad forbinder disse forfattertyper, og hvad bringer sammen her? Der rejser sig nu flere spørgsmål. For det første: kan tegningerne dateres? For det andet: har tegneren kendt Hamsun og Esmann, og har han haft modellerne for sig og hvorhenne? Og er der endelig nogen forbindelse til Finds portrætter på Frederiksborg Museet?

Brevet med tegningerne er fra forfatteren Carl Ewald. ${ }^{9}$ Det findes blandt Ludvig Finds efterladte papirer på Det Kongelige Bibliotek. ${ }^{10}$ Brevsamlingen rummer bl.a. breve fra malerkammerater, og en række forfattere, som Find havde bekendtskaber eller livslange venskaber med: fx Sophus Claussen, Johannes Jørgensen, Carl Ewald, Agnes Henningsen, og Johannes V. Jensen. Nogle breve belyser blot venskabsgraden gennem invitationer og fødselsdagshilsner, andre dokumenterer Finds forbindelser til de kunstner- og forfattermiljøer, der frekventerede Cafe Bernina og andre af byens halv- og helmondæne etablissementer. ${ }^{11}$

Efter hjemkomsten fra Amerika i sommeren 1888 opholdt Knut Hamsun sig et lille års tid i København, hvor han som bekendt vakte opsigt med sine første kapitler af Sult i Carl Behrens' tidsskrift $\mathrm{Ny}$ Jord og blev sensation i de litterære kredse. ${ }^{12} \mathrm{I}$ de følgende år 
frem til 1906 var Hamsun ofte tilbage på kortere eller længere ophold, og det er velkendt, at det gik både lystigt og vildt til, når rejsestipendierne blev omsat til 'rangel' i København.

Esmann, i samtiden kendt for sin slagfærdighed og skarpe tunge, beundret for sine vittige lystspil og frygtet for sine respektløse teateranmeldelser, huskes nu især for de mange skandaleoptrin som for eksempel overfaldet på Edvard Brandes på Helsingør banegård, pistolduellen ved Fortunen, og især for hans pludselige og voldsomme død. Indtil elskerindens revolverkugle ramte ham 4. september 1904 var levemanden Esmann en velkendt figur på strækningen fra Tivoli til Kongens Nytorv, hvor datidens kulturelite yndede at mødes eller lade sig se i Nimb, Wivel, Dagmarcafeen, Cirkus Varieté, Bernina, Kisten, Rydbergs Kælder og Guldkuren. $^{13}$

Find var nær ven med nogle af dem, der var med, "når Knut Hamsun kom ned fra sit Norge og fyldte det literære København som et Fjældskred ... $" 14$ - venner som Johannes Jørgensen og senere Johannes V. Jensen, der oprindelig frydedes men blev betænkelig ved Hamsuns sublime vanvid, som han udødeliggjorde i Helled Haagen-digtet. ${ }^{15}$ Nogen nærmere berøring med de Esmannske cirkler synes Find derimod ikke at have haft.

Ligesom Johannes Jørgensen befandt Find sig en tid i spændingsfeltet mellem Carl Ewalds fritænkeri og

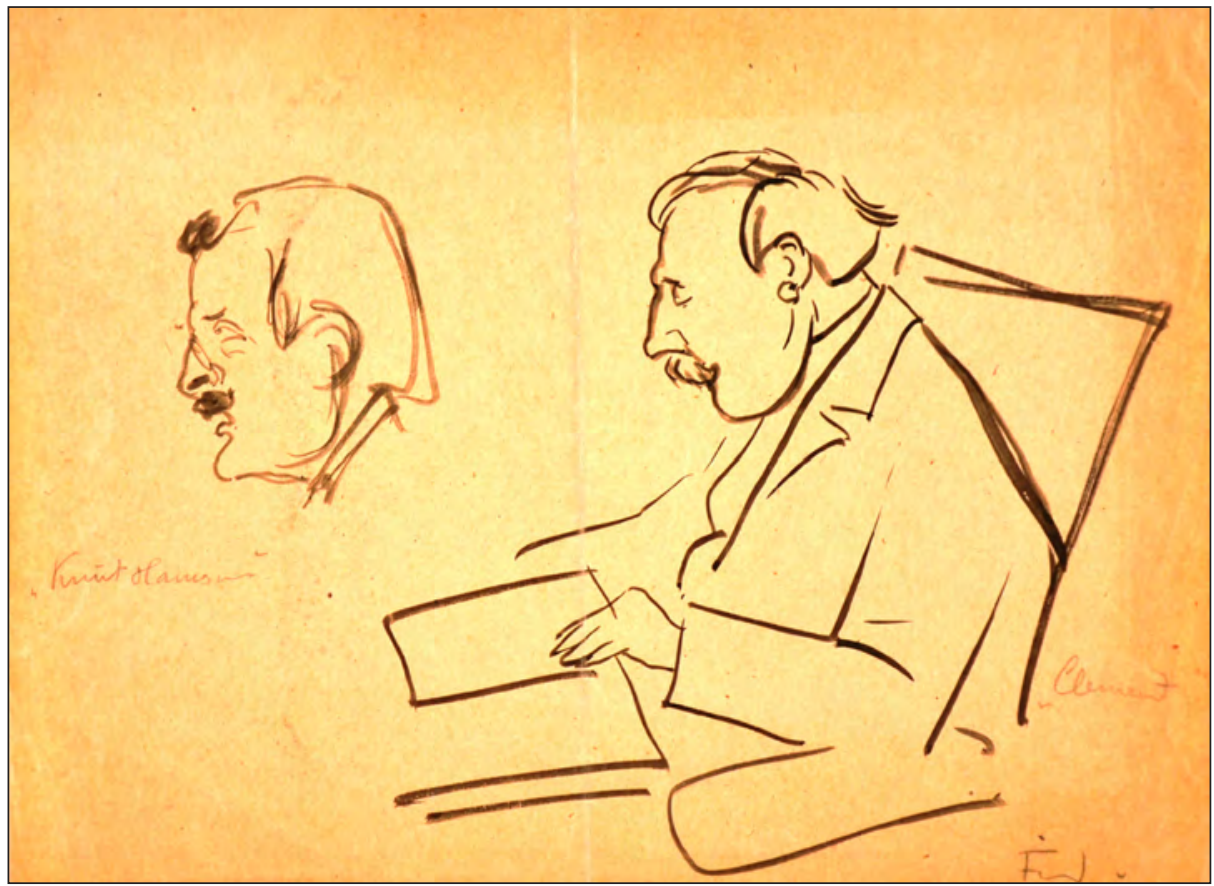

Knut Hamsun og maleren Gad Fr. Clement. Tusch og pensel. Udateret ark med portratter signeret af Ludvig Find (Frederiksborgmuseet). 
Mogens Ballins kristelige reaktion. Han undgik at blive draget med over i katolicismen og fandt et ståsted i den grundtvigske valgmenighed. Men han bevarede venskabet med dem alle.

Kunstnerisk brød han med den symbolistiske retning, han en tid havde været en af foregangsmændene for og fandt sin egen form med motiver fra de nære omgivelser og det hjemlige familieliv. Efterhånden skabte han sig også en position som skattet portrætmaler.

Redaktør Carl Behrens nævner Find, som i 1888 havde malet en kraftig øjebliksskitse af ham, blandt de skønånder, der samledes i hans hjem, hvor også Hamsun var blevet bekendt med Sophus Claussen, Viggo Stuckenberg og Johannes Jørgensen. ${ }^{16}$ Nogen sikker viden om et nærmere personligt bekendtskab med den norske forfatter foreligger ikke; men at Find i et selskab med fælles venner kunne komme på "tegnehold" af ham, har været en mulighed allerede fra den første tid i Kobenhavn.

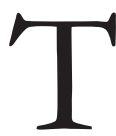

egningerne i Carl Ewalds brev må dog være blevet til efter Hamsuns anlæggelse af den strindbergske moustache og før Esmanns død. Det vil sige perioden mellem 1893 og 1904. Det lader sig imidlertid gøre at indsnævre tidsrummet yderligere. Det udaterede brev indeholder $\mathrm{i}$ al sin korthed følgende besked:

Kære Find! / Hvis du ser ind i Tivoli i aften / finder du os Kl 8 hos Nimb. - / Imorgen tidlig rejser vi til Trelde,

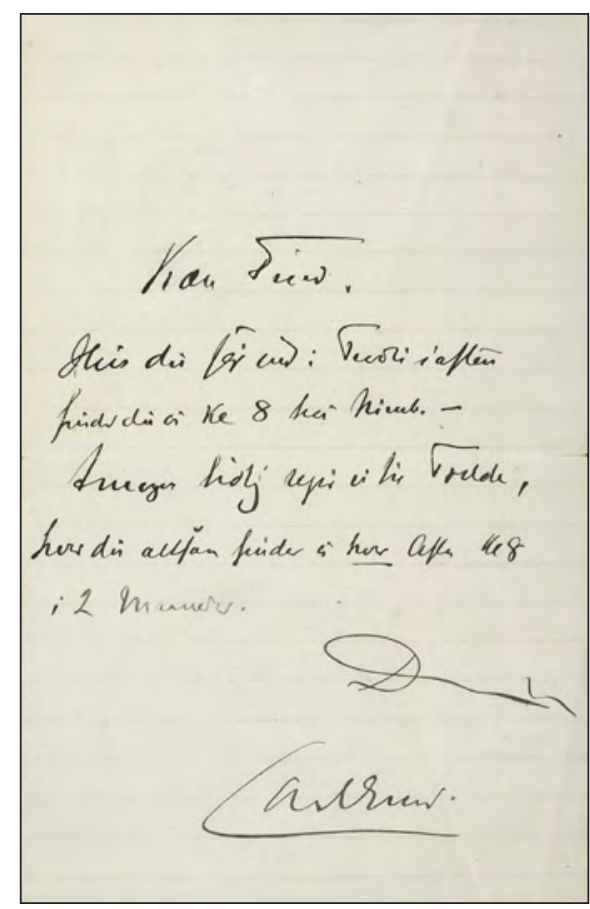

/ hvor du altsaa finder os hver Aften Kl 8 / i 2 Maaneder.

\section{Carl Ewald.}

$\mathrm{D}[$ in Ven]

Om familien Ewalds sommerophold på Trelde Næs ved Lillebælt nord for Fredericia skriver Lissen Ewald i sin erindringsbog: "... Senere var vi to Aar i Træk i Trelde. Far fandt Huset ved at læse en Annonce i en gammel Avis, engang han var paa Das. ... Ogsaa min Halvsøster, Karen, var med i Trelde. Hun og hendes tre Aar ældre søster Ellen kom til os i 1902. De var Døtre af Fars første Ægteskab - Karen var sytten År ... ... Den anden Sommer i Trelde var jeg i Lømmelalderen. ...." I samme bog er der gengivet fotografier af den Ewaldske storfamilie i Trelde fra $1903 .^{17}$ 
Brevet kan på denne baggrund dateres til 1902 eller 1903 ved Tivolisæsonens begyndelse. I 1903 kan en afrejsedato yderligere indkredses ved hjælp af breve fra fru Betty Ewald til Find. En invitation dateret 11.6.1903 til frokost den følgende tirsdag viser, at familien endnu ikke er rejst tirsdag den 16. juni. Af Bettys næste breve fremgår det, at Ewalds vil vende hjem engang i den sidste uge af august måned. De to måneders træffetid i Trelde passer således til en afrejsedag fra København i slutningen af juni. Et tidspunkt der sikkert også hænger sammen med skolernes sommerferie. Fru Ewald var nemlig lærerinde på Gasværkvejens Betalingsskole. Det samme gælder formentlig for 1902, som imidlertid kan udelukkes, da Find omkring Sankt Hans var i Randers. ${ }^{18}$ Brevet må derfor dateres til sidste uge af juni 1903. Og at Find netop i det tidsrum kunne blive øjenvidne til en "Hamsunrangel" i København, vil fremgå af det følgende.

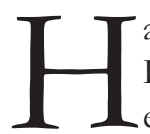
amsun er nede i en bølgedal. Kunstnerisk og ægteskabeligt er han i dyb krise og flygter helst fra konen og deres nyfødte datter. Legenderne om hans eskapader og langvarige drukture stammer fra denne periode, hvor vildskaben accelererer og kulminerer i $1906 .{ }^{19}$

I sommeren 1903 er han på et flere måneders langt stipendieophold i København. ${ }^{20}$ Hamsun bor på Grand Hotel Nilson i Holbergsgade og skriver 1. august:

... jeg har nu boet her et Par Maaneder og skal blive boende her, men min Hustru og lille vidunderlige Datter er i Kristiania fordi den lille var for liden at rejse med endda. Jeg har Stipendium nu og maa derfor være borte fra Norge. Jeg er netop blevet færdig med et tre Akts Skuespil "Dronning Tamara" (fra Kaukasien), jeg tror det er godt, har nu indleveret det til det kongelige Teater her. ${ }^{21}$

Han har altså allerede været i byen fra begyndelsen af juni. At der blev sviret, når Hamsun var i København, var som nævnt uundgåeligt, naturligvis med tilhørende tømmermænd. Selv skriver han angående teaterstykket til Gyldendals konsulent, digteren L.C. Nielsen, der øjensynligt under sit sommerophold i Hornbæk har inviteret ham derop:

... Jeg kan af forskellige Grunde ikke komme til Dem, ellers Tak for venligheden, jeg er nervøs til det yderste netop nu, og i Hornbæk er desuden Sven Lange, saa kommer jeg paa Rangel, og saa blir jeg værre. ...Jeg vil også indlevere det [manuskriptet] til det kgl. Teater, .... Vil De være saa snil at faa Deres Bror til at læse det? Jeg tror nok Einar Chr. antager det; men Knuden er at faa det opfort, og her sagde Gustav Esmann, at Deres Bror kunde hjælpe mig ... Hvis der er meget De vil sige mig ang. Stykket kommer jeg til Dem naar jeg er bleven lidt bedre af den megen Nervøsitet. ${ }^{22}$

Den gamle ven fra Parisårene, forfatteren Sven Lange, der i mellemtiden har opnået en position som dramatiker og 
teaterkritiker, var på sommerophold i Hornbæk fra den 21. juni til 3. august. ${ }^{23}$ Hamsun har haft lejlighed til at træffe ham i København tidligere i juni, og som det fremgår af breve igen $i$ august. Under og mellem cafébesøgene har man drøftet opsætningsmulighederne for det nye stykke i København, for Hamsun skriver optimistisk hjem:

.... Skal nok greje alt, skal du se, alt tyder paa det. Har været hos kgl. Teater, Chefen gav mig det bedste Haab, han har nu læst "Tamara" og han pegte selv ud de "nydelige" Scener, og at der var nydelige scener overalt. ... Nu har også Sven Lange og Peter Nansen læst det og finder det næsten sikkert at kgl. tager det. .... ${ }^{24}$

Den hamsunske nervøsitet blev selvfølgelig altid forstærket af pengemangel og moralske tømmermænd. Allerede efter en lille måned på stipendium var kassen tom. Den 30. juni afgik et bønskrift til hans norske forlægger om et lån:

... Jeg skal have et Stykke færdigt som skulde op paa Nationalteatret næste Sæson ... men jeg faar ikke sidde $\mathrm{i}$ fred, jeg er desværre kommet saa dybt paa Knæerne. Jeg vilde bede Dem være saa snil at hjælpe mig noget hvis det er muligt for Dem. Jeg skal betale Dem tilbage enten med Manuskript eller af Teaterpengene til Vinters og skal være taknemmelig for hvad De kan sende. ... ${ }^{25}$

12. juli takkes for et forskud på 1000 Mark fra den tyske forlægger. ${ }^{26}$ Der kan igen blive råd til flere ture med de gamle drikkebrødre, og rangelen fortsætter med uformindsket styrke til han rejser hjem til Norge, som følgende klip fra de sidste åbenhjertige breve til hans finske ven bevidner:

Jeg skælver af drukkenskab, derfor skriver jeg med Blyant. [24. august]

Fy Fan hvor er jeg fuld i dag fra i

Nat. Gid du var her, Hagelstam! [13. september]

Jeg rejser i dag til Kristiania. Jeg kom ikke af sted til dig for jeg kom paa Rangel og begyndte at bruse ganske Satans - [18. september $]^{27}$

Tidligere havde han forsøgt sig med beroligende bortforklaringer og undskyldninger. Fru Bergljot derhjemme fik en forsikring om, at han blot

... sad paa en Kafe med Sven Lange

og Gustav Esmann og en mand som hedder Marer, og vi fire pimped lidt Pjolter og det var alt. ... ${ }^{28}$

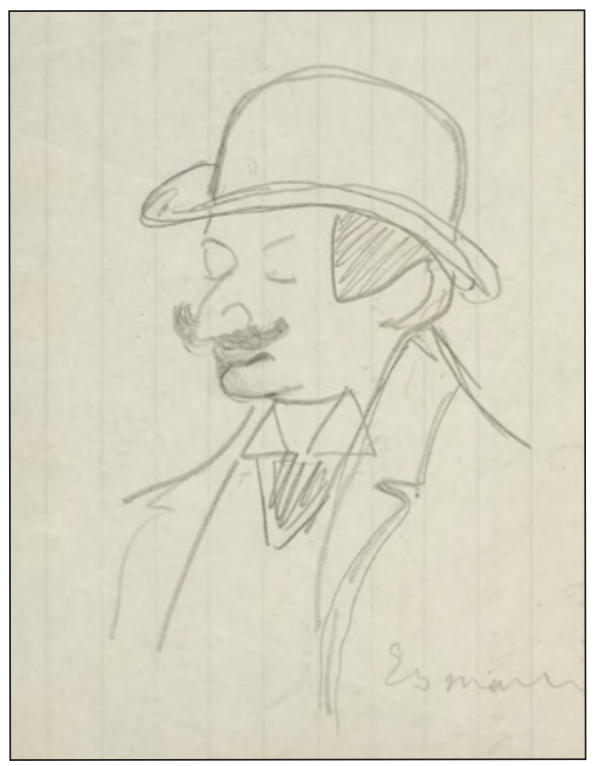

Gustav Esmann. Blyantstegning af Ludvig Find. Bagside af Carl Ewalds brev (Det Kongelige Bibliotek). 
Et sammentræf med dette kompagni har altså været overordentlig sandsynligt, hvis man bevægede sig ud i det københavnske forlystelsesliv i sommermånederne 1903. Carl Ewalds brev med Finds tegninger lader formode, at en dag i slutningen af juni kunne d'herrer Esmann og Hamsun træffes i Tivoli.

Ad en lidt anden vej lader det sig imidlertid gøre at fastslå den nøjagtige dato for både brev og sammentræf. Et løst blad med Findskitser, som er fremdraget $i$ anden forbindelse, viser sig at være den anden halvdel af Carl
Ewalds brevark. Brevet har haft 4 sider, hvoraf kun den første er beskrevet.

Sammenfoldet kunne resten benyttes som skitseblok med 6 felter.

I et af felterne ses en ung pige under en stor blomsterprydet hat, med et par fingre om vinglassets stilk i passende afstand fra bordkanten. I feltet til høje er en lang herre ved at indtage et måltid; vinglassene er ikke vendt for at blive taget $\mathrm{i}$ brug, et almindeligt glas antyder at han har foretrukket en anden drik til maden. Pigeportrættet er betegnet Karen Ewald. Bordherren kan
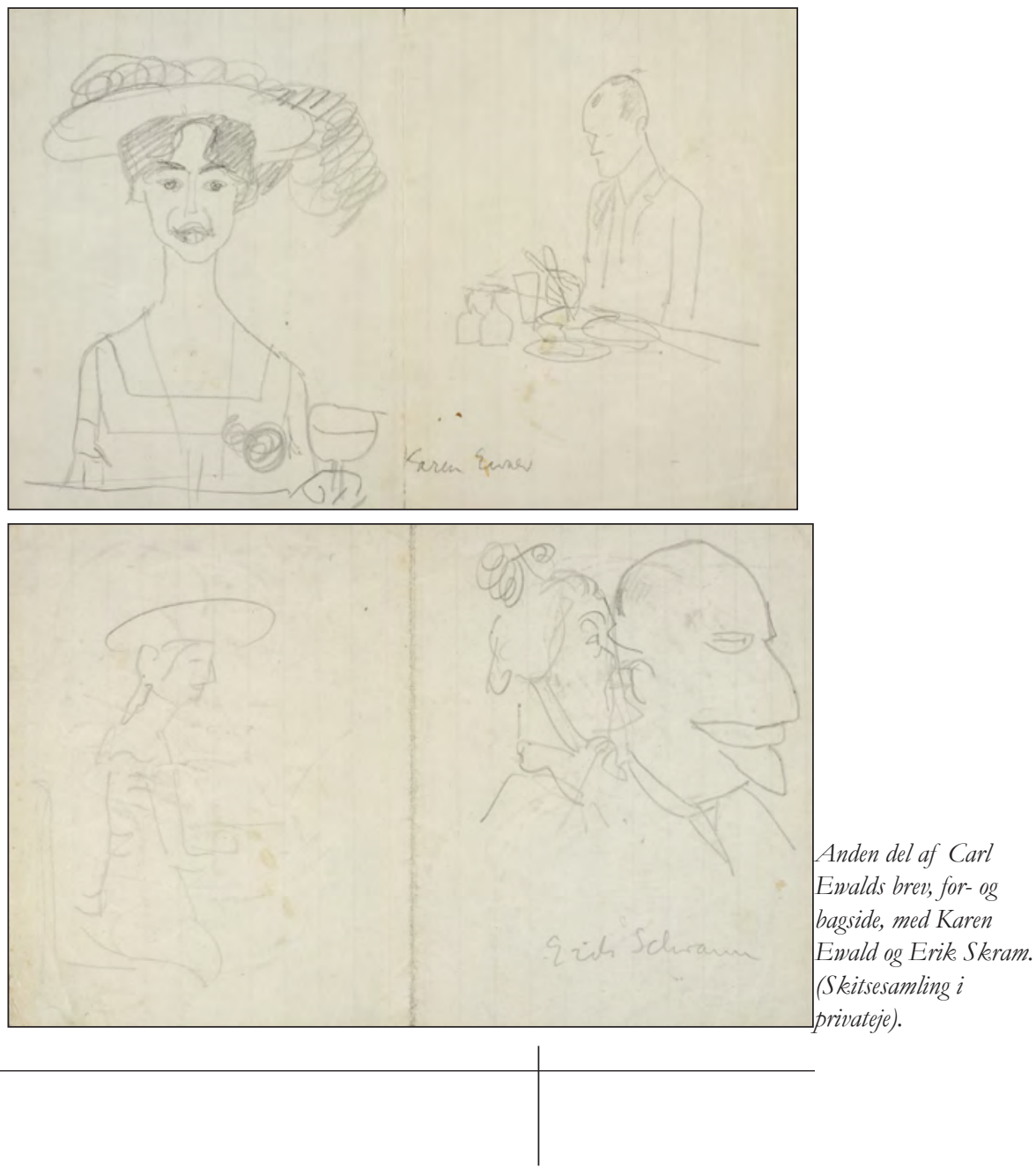


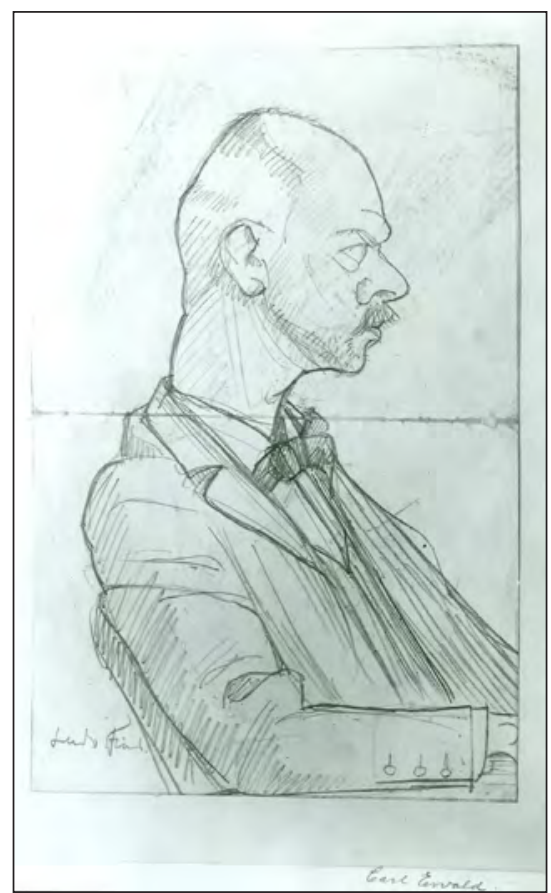

Carl Ewald. Blyantstegning af Ludvig Find (udateret) (Frederiksborgmuseet).

være Carl Ewald tegnet uden karikerede træk. Ofte sås han i byen sammen med sin store pige, hans nu 18-årige datter. ${ }^{29}$ Hun skulle som nævnt netop den sommer igen med Ewald-familien til Trelde. Ludvig Find har altså fulgt opfordringen til at møde sin gode ven Carl Ewald før dennes afrejse til Jylland, har stukket brevet i lommen og er gået i Tivoli og har aftegnet selskabet på det stykke papir, han nu havde ved hånden.

På et tidspunkt er disse portrætskitser blevet skilt fra brevet og sammen med andre løse tegninger lagt ind i en af Finds skitseblokke. ${ }^{30}$ På bagsiden af denne papirlap (egentlig på samme opslag som Esmann og Hamsun) er der nogle løst skitserede kvindeskikkelser og en let genkendelig profil i enkel konturstreg betegnet Erik Schram.

Forfatterparret Erik og Amalie Skram var Hamsuns tidlige støtter. Deres ægteskab var ophørt, og de havde faktisk også slået hånden af Hamsun, men måske var Skram atter i Tivoli med gamle drikkebrødre. ${ }^{31}$

Imellem Skrams efterladte papirer på Det Kongelige Bibliotek findes hans almanakker fra årene 1900-1907 bevaret. Kalenderen indeholder såvel aftaler som korte dagbogsnotitser. For det meste begivenheder af selskabelig art som frokost eller middag sammen med bekendte fra kulturlivet eller det højere borgerskab. ${ }^{32}$ I juni måned 1903:

Den 26 Hos Nimbs i Tivoli med Jürgensen og Frue og Pio - Wivels Veranda, hjemme Kl 2.

Navnene forekommer andre steder i Skrams almanak i de år: Grosserer Dethlef Jürgensen, hans hustru Ruth og skuespilleren William Pio. ${ }^{33}$ Erik Skrams tilstedeværelse i Restaurant Nimb denne sommeraften er hermed givet. Og Finds

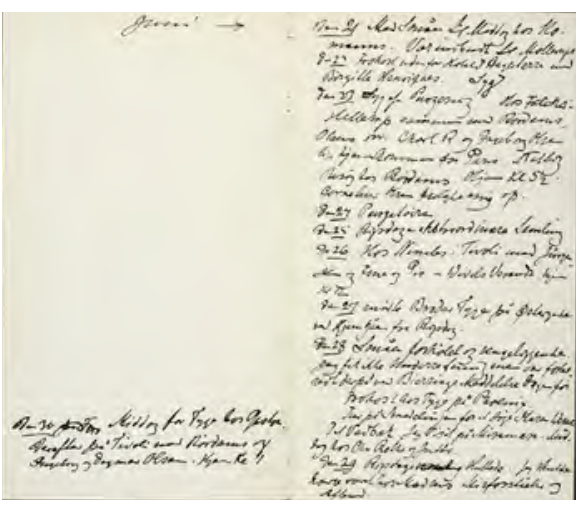

Erik Skrams almanak 1903. Juni måned fra den 21. til den 30. (Det Kongelige Bibliotek). 


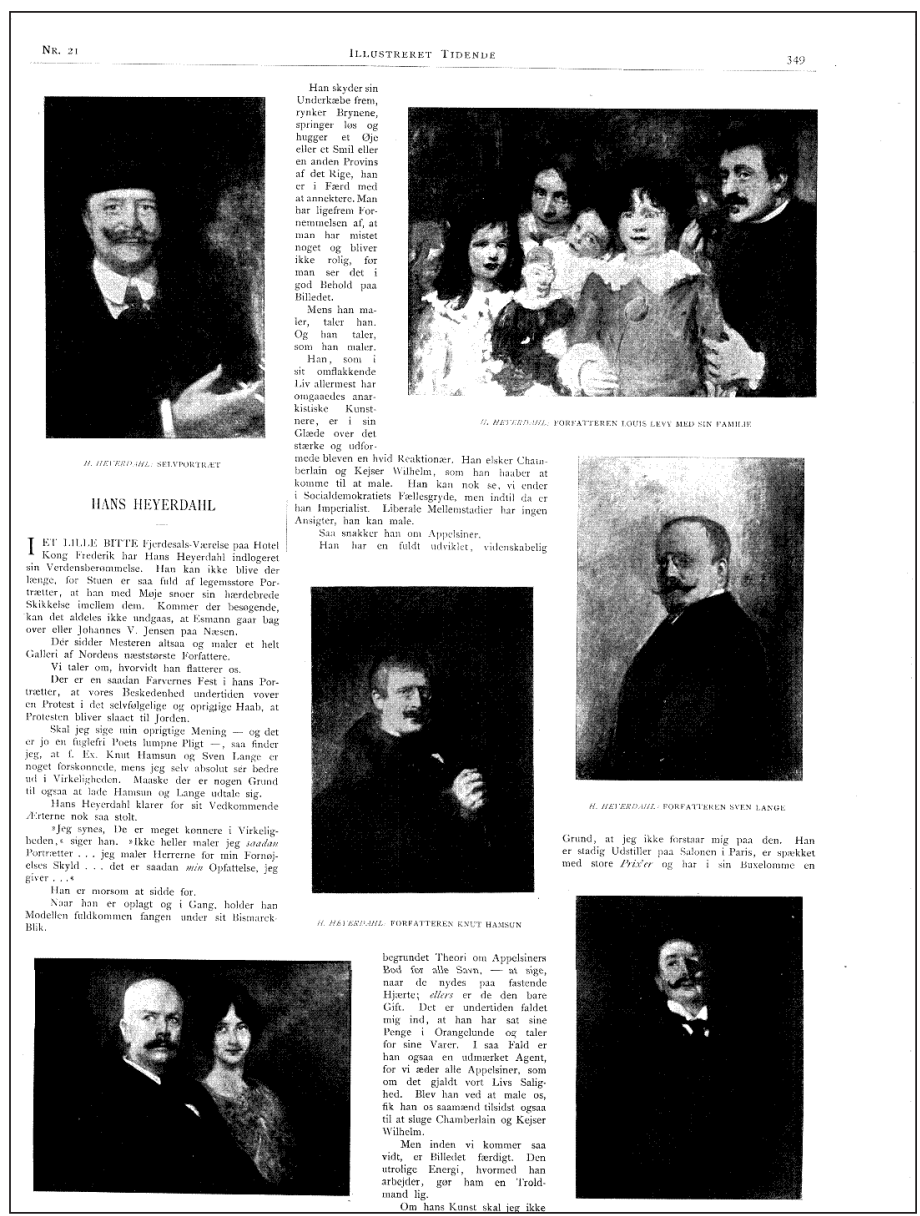

Hans Heyerdahls maleri fra 1903 af Hamsun $i$ pels og med stok gengivet forste gang $i$ Ewalds prasentationsartikel sammen med andre portratter, bl.a. af denne artikels hovedpersoner Esmann, Lange og Carl Ewalds og hans datter. Heyerdabl malede $i$ Kobenhavn 190304 og udstillede et par af billederne på Charlottenborgs Forårsudstilling 1904. Illustreret Tidende 21.2.1904. Illustreret Tidende Online 1859. 1924 - Det Kongelige Bibliotek

tegninger af Erik Skram, Gustav Esmann og Knut Hamsun er hermed både tids- og stedfæstet: fredag den 26. juni 1903 i Tivoli. $^{34}$

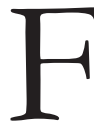

ind havde allerede leveret illustrationer til flere bøger og tidsskrifter og udstillet portrætmalerier, men var endnu ikke kommet i betragtning ved tildelinger af offentlige portrætopgaver. Skitser og karikaturer af kendte og ukendte personer findes over- alt i skitsebøgerne, på papirlapper og $\mathrm{i}$ brevene. Et par paparazzi-tegninger med kendte københavnertyper fra nattelivet kunne måske afsættes til boulevardpressen. Men der er ikke noget, der tyder på at Find havde held til at trænge ind på bladtegnernes marked. Et brev fra Ekstrabladets Frejlif Olsen viser, at Find på et tidspunkt har forsøgt at afsætte nogle tegninger, men han får et venligt afslag med henvisning til, at hans hidtil mest anvendte blyantsteknik ikke var egnet til 
gengivelse $i$ avistryk. ${ }^{35}$

I Frederiksborgmuseets portrætsamling ${ }^{36}$ findes en separat Find-karikatur af Skram. ${ }^{37}$ Den er næsten identisk med brev-tegningens konturstreg og ligeledes udført med blyant, og udaterede blyantsportrætter af Carl Ewald og Sven Lange stammer sandsynligvis fra samme periode. ${ }^{38}$ Frederiksborgmuseets udaterede Hamsunprofil er udført med tusch og pensel på et ark, hvor han også har anbragt malerkammeraten Clement. ${ }^{39}$ Ligheden med Nimb-karikaturen er slående og tyder på, at tuschudgaven er tegnet op efter blyantsudgaven. ${ }^{40}$ Den er en anelse større, men munden, moustachen og øjenpartiet er præcist overført. Pandens skrånen, hårlokken og kæbepartiet, som på fotografier af Hamsun ses at høre til fysiognomiets karakteristika, er klart opfattet og karikeret på blyantstegningen, men i tuschudgaven er karikaturelementerne helt fjernet og profilens proportioner reguleret. Dette kunne også tale for, at det er en senere overførsel af det hastige øjebliksnotat fra Tivoli.

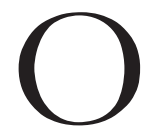
$\mathrm{m}$ et portræt er vellykket eller ligner, beror på noget andet end rent fotografisk lighed.

Og som bekendt ligner en karikatur ofte bedre end et foto eller officielt portræt. Når begge Finds skitser nu, efter at tid og sted er fastslået, betragtes ved siden af de samtidige portrætter, vil man se, at Finds streger også har indfanget noget, som ellers bliver holdt skjult $i$ atelierfotografierne, hvor forfatteren ofte er iscenesat som magtfuldt viljesmenneske. I 1903 var det ikke længere en apollinsk yngling, men en midaldrene dionysisk satyr, der

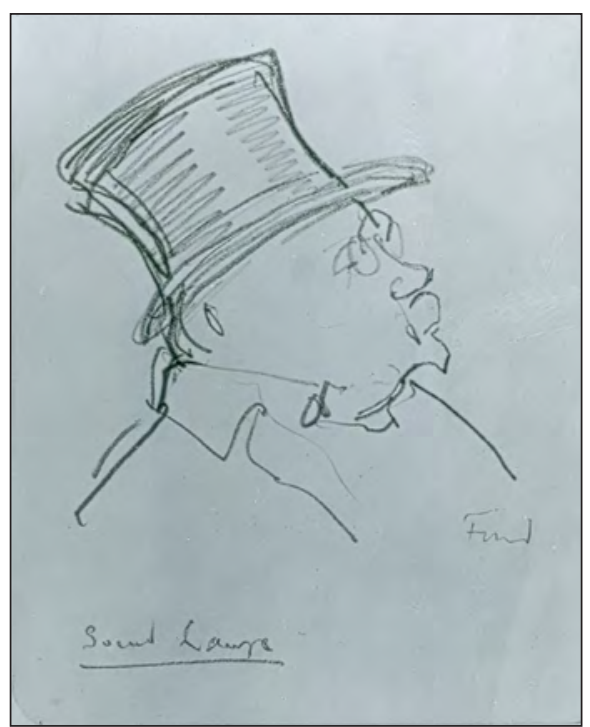

Fig. 6. Sven Lange. Udateret blyantstegning af Ludvig Find (Frederiksborgmuseet).

søgte stimulans og inspiration i cafelivet sammen med datidens mer eller mindre ligesindede skønånder.

I april 1903 modellerede

Gustav Vigeland en buste af Hamsun.

"Han var en meget brysom model. Hver dag i bakrus. Enkelte gange synlig drukken! Det var rart det blev noen buste!" og Vigeland skal selv have fortalt at Hamsun "sat omgit av en mængde ölflasker" mens han sad model. ${ }^{41}$ Også på Hans Heyerdahls kendte portræt fra samme år er Hamsun tilsyneladende i en lignende tilstand. Eller også har maleren forskønnet ham, som Carl Ewald hævder i sin omtale af Heyerdahls billeder. ${ }^{42}$ I Tivoli med Esmann er Hamsun fanget på et mere indledende eller opløftet stadium af en 'rangel', og Finds førstehånds tegning supplerer således de samtidige portrætter af "Kæmpen med den nervøst dirrende Sensibilitet, 
det levende snart skalkagtige, snart bitre Smil og de underligt fjerne $\varnothing j$ je - i hans urolige instinktive geniale Aand samlede der sig meget af denne Epokes spredte Stemninger og flygtige Tanker som i et Brændpunkt."43

Noter

1 For andre oplysninger og opmuntrende interesse takker jeg medarbejderne ved Håndskriftafdelingen og Kirsten Hedvig Rasmussen, Karlsruhe, Hamsun Selskapets ambassadør og redaktør af webstedet wmm. hamsun.at

2 Sophus Claussen, Jord og Sjal (1917). Erindringer, Noveller og litterær Journalistik. I udvalg ved Stig Krabbe Barfoed. 1961, s. 174.

3 Hamsun med kridtpibe. Oliemaleri af Alfred Emil Andersen, Kristiansand 1891. Nationalgalleriet i Oslo.

4 Se fx Hamsun. Eine Bildbiographie von Marianne Hamsun. Kindlers klassische Bildbiographien. München 1959. Øystein Rottem, Hamsuns liv i bilder. Oslo 1996.

5 Norske Portretter. Forfattere. Med innledning av Francis Bull. Utgitt av Norsk

Portrettarkiv. Riksantikvariatet Oslo 1956. Arvid Østby, Knut Hamsun - En bibliografi. Oslo 1972, s. 277-279. Her finder man ikke Sophus Claussens skitse fra Paris 1893; den kom først for dagen efter at Claussens notesbøger i Det kongelige Biblioteks håndskriftsamling blev tilgængelige ved udløbet af 1981. Portrættet findes i notesbog 30b. NKS 1340 oktav. Gengivet i Frans Lasson, Sophus Claussen og hans kreds. En digters liv i breve. 1984. Bd. 1, ml. 176-77.

6 Ludvig Find (1869-1945), maler. Merete Bodelsen, Maleren Ludvig Find, 1943. Weilbach. Dansk kunstnerleksikon. 2. bind. 1994.

7 Eddie Salicath, Omkring Gustav Wied. 1946, pl. III. Frederiksborgmuseet, inventar nr. A 3910, findes ikke registret i de ovennævnte værker, men er indført i Norsk Portrettarkivs database.
8 Gustav Esmann (1860-1904). Journalist, forfatter, dramatiker. Se note 13.

9 Carl Ewald (1856-1908) Journalist og forfatter. Trods et omfattende forfatterskab (bl.a de engang meget yndede eventyr), synes han nu kun at huskes for sit forhold til Agnes Henningsen og det biologiske faderskab til PH (Poul Henningsen).

10 NKS 5210 kvart. Arkivet, der indeholder breve til og fra Ludvig Find, personalia, manuskripter og optegnelser, blev oprindelig i 1955 af arvingerne skænket til Den Hirschsprungske Samling. I 1979 overdraget til Det Kongelige Bibliotek. Papirerne er blevet delvist ordnet i flere omgange, men en brevregistrant er først nu blevet udarbejdet og gjort tilgængelig $i$ forbindelse med et supplement til samlingen (Acc 2009/62). Af de 17 breve fra Carl Ewald, er det tidligste af de 8 daterede fra december 1894, det sidste fra 7. februar 1908 kort før Ewalds død. De fleste af de 9 udaterede kan ud fra indholdet henføres til 1895.

11 Det var Carl Ewald og Agnes Henningsen, der i 90'erne var midtpunkt i Finds "Bernina-periode". Agnes Henningsens erindringsbøger. Letsindighedens Gave. 1943. Byen Erobret. 1945. Johs. Jørgensen, Mit Livs Legende (1947) I, s. 137, 146. Aage Welblund, Omkring den literare café. 1951, s. 101.

12 Carl Behrens: Erindringer. Mennesker og Begivenheder. 1937, s. 116. Johs. Jørgensen, Mit Livs Legende. (1947), I, s. $91 \mathrm{f}$.

13 Den bedste karakteristik af Esmanns personlighed er givet af Sven Lange: Gustav Esmann (16.6.1905): Meninger om Litteratur, samlede og udgivne ved Oskar Thyregod. 1929, s. 189-192. Det anekdotiske stof er samlet i Aage Welblund, Omkring den literare café. 1951, s. 83-101

14 Johs. Jørgensen, Mit Livs Legende (1947), s. 125f., 137, 146

15 Johs. V. Jensen, Skovene (1904); Digte 1906. 16 Carl Behrens, Erindringer. Mennesker og 
Begivenheder. 1937, s. 116. Ludvig Find kom til København i 1885 for at blive kunstmaler.

17 Lissen Ewald, Carl Ewald og hans Kone. 1946, s. $27 \mathrm{ff}$. og 46. Lissen Ewald (1890-1908), maler. Karen Ewald (1885-1954), forfatter.

18 Brevkort til Maleren L. Find / Hotel Randers / Randers / Poststempel 24.6.1902 fra Tupsy Clement. NKS 5210 kvart. Jf. brev fra Aage Bertelsen til Svend Hammershøi: "Randers Juli 1903 .... Find bor her hos W. [Amtsforvalter A. Wilde] han skal illustrere en Bog af Pontoppidan der hedder "Minder" Han er meget fortvivlet over det, som du vel kan begribe. Find er hyggelig og prægtig, som han jo gerne er, naar han er paa Landet;..." Aage Bertelsens brevsamling. KB Acc 1978/26. Find illustrerede 1902-udgaven af Minder med motiver fra Randers.

19 Se fx Jørgen Haugan, Solgudens fall, Oslo 2004, s. $171 \mathrm{ff} .$, og øjenvidneskildringerne i Steen Drewsen, En Kvarulant ser tilbage. 1937, s. 195-210.

20 Knut Hamsuns brev 1896-1907. Utgitt av Harald S. Næss. Oslo 1995. Fra København 1903 er der 14 breve til forskellige afsendt herfra mellem 30. juni og 18. september.

21 Ibid., s. 234f., udateret brev til Wenzel Hagelstam (1863-1932), finsk journalist, forfatter og forlægger, som Hamsun havde lært at kende i Helsingfors i 1899.

22 Ibid., s. 234, udateret brev til L.C. Nielsen (1871-1930), forfatter, redaktør. 1901-1908 konsulent på Gyldendal. Sven Lange (18681930), forfatter, litteratur- og teaterkritiker. Hamsuns ven fra årene i Paris 1893-95 og nær bekendt af Esmann. Einar Christiansen (1861-1939), Det kgl. Teaters direktør 1899-1909. L.C. Nielsens broder Johannes Nielsen (1870-1935), skuespiller og sceneinstruktør, økonomiinspektør ved Det kgl. Teater.

23 Datoer fremgår af Sven Langes breve til Johannes Marer. KB Palsbo Aa, Sp, 54.

24 Knut Hamsuns brev 1896-1907, s. 236, udateret brev til Bergljot Hamsun. Teaterstykket udkom hos Gyldendal i september 1903, men blev aldrig sat op i København.

25 Ibid., s. 230, til Lars Swanström (18681939). Svensk-norsk forlagsboghandler.

Leder af Cammermeyers forlag $\mathrm{i}$

Kristiania.

26 Ibid., s. 231, til Albert Langen (1869-1909).

Forlægger i München. Udgiver af det satiriske blad Simplicissimus.

27 Ibid., s. 242f., breve til Wentzel Hagelstam.

28 Ibid., s. 237, udateret brev til Bergliot Hamsun. Johannes Marer (1861-1922) skuespiller, oversætter, grafolog.

29 Aage Welblund, Omkring den litercere café. 1951, s. 109. Carl Ewald, Min store Pige. 1904.

30 Skitseblok i privat eje.

31 Erik Skram (1847-1933) indtil 1900 gift med Amalie S. (1846-1905).

32 Erik Skrams Papirer. I Personalia. e. Dagbøger. NKS 4501, kvart.

33 Dethlef Jürgensen (1873-1947), kaffe- og smørgrosserer. Ruth Jürgensen, f. Hansen (1876-1952). William Pio (1850-1909), skuespiller.

34 Er det mon tilfældigt at Ewald i sit delvis selvbiografiske programskrift om frisind og pigeopvækst henlægger en vigtig samtale med datteren til: "... Fredag den 26de Klokken 71/2 e.M."? Carl Ewald, Min Store Pige, 1904, s. 109.

35 Frejlif Olsen til L.Find 11.1.1908. NKS 5210 kvart.

36 Det Nationalhistoriske Museum Frederiksborg Slot. Af Ludvig Find er der 48 tegninger af 36 forskellige forfattere, kunstnere, skuespillere og erhvervsfolk med dateringer mellem 1890 og 1908; 22 er udaterede. (Købt 1927 for 125 kr.).

37 Inventar nr. A 3915. Den er udateret og betegnet Erik Schram, ligesom den første tegning. På flere af samlingens portrætter er navnet senere tilføjet med blyant. Det gælder også brevtegningerne af Esmann, Karen Ewald og Skram, som ikke kom med i museumssamlingen.

38 Inventar nr. A 3927 og A 3906. Begge gengivet i Eddie Salicath, Omkring Gustav 
Wied. 1946, pl. XIII.

39 Inventar nr. A 3910. Placering: P 123, pl. 166.

40 Flere lignende eksempler på tusch-udgaver efter blyantsforlæg: Fx inventar nr. A 3914: Aage Bertelsen, Sven Hammershøi og Herman Kähler, og inventar nr. A 3934: Rudolf Bertelsen. Blyantsforlæggene findes $i$ en privatejet skitsebog.
41 Vigeland og Hamsun. www.vigeland. museum.no/images/stories/aktuelt/ vigeland_og_hamsun_lr.pdf

42 Illustreret Tidende Årg. 45, nr. 21, 21.2.1904, s. 349f. Illustreret Tidende Online 18591924 - Det Kongelige Bibliotek: www. illustrerettidende.dk

43 Sven Lange (20.11.1920): Meninger om Litteratur, samlede og udgivne ved Oskar Thyregod. 1929, s. 226. 